\title{
Arsenic Exposure, Dermatological Lesions, Hypertension, and Chromosomal Abnormalities among People in a Rural Community of Northwest Iran
}

\author{
Saeed Dastgiri', Mohammad Mosaferi², Mohammad A.H. Fizi ${ }^{3}$, Nahid Olfati', \\ Shahin Zolali ${ }^{4}$, Nasser Pouladi ${ }^{5}$, and Parvin Azarfam ${ }^{3}$ \\ 'School of Medicine and National Public Health Management Centre, ${ }^{2}$ School of Public Health and Nutrition, ${ }^{3}$ Tabriz University, Tabriz, \\ Iran, ${ }^{4}$ Academic Center for Education, Culture and Research, Tabriz, Iran, and ${ }^{5}$ Azarbaijan University of Tarbiat, Moallem, Tabriz, Iran
}

\begin{abstract}
Chronic exposure to arsenic compounds is one of the major public-health problems in many developing and some developed countries. The aim of this study was to investigate the effects of chronic exposure to arsenic on dermatological lesions, hypertension, and chromosomal abnormalities among people in a community in the northwest of Iran. The occurrence of dermatological lesions, hypertension, and chromosomal abnormalities was investigated in two groups: Ghopuz village, including 101 subjects with chronic exposure to arsenic in drinking-water and Mayan village, including 107 subjects with no exposure. Daily/ yearly absorbed amounts of arsenic were calculated for all subjects. Cumulative arsenic index for each individual was then estimated on the basis of age, water consumption, and location of residence. Arsenic concentration in drinking-water sources in Ghopuz and Mayan villages was $1031 \pm 1103 \mu \mathrm{g} / \mathrm{L}$ and nondetectable respectively. The mean systolic blood pressure in the exposure group [ $\mathrm{n}=137,95 \%$ confidence interval (CI 132-142)] was significantly higher than that in the control group ( $\mathrm{n}=107,95 \%$ CI 99.9-114). A similar significant difference was observed for diastolic blood pressure (exposed: $n=82,95 \%$ CI 79-85 vs non-exposed: $\mathrm{n}=71,95 \%$ CI 66-75). The incidence of hyperkeratosis was 34 times higher among the exposure group compared to the control subjects [odds ratio $(\mathrm{OR})=34, \mathrm{p}<0.001)$ ]. A significant difference was also observed in the occurrence of skin-pigmentation between the two groups ( $\mathrm{OR}=2.4, \mathrm{p}<0.007)$. Location and severity of the pigmentations were statistically different between the two groups. Twenty-five percent of the subjects in the exposure group showed chromosomal abnormalities ( $\mathrm{p}=0.05)$. Arsenic exposure was a serious health problem in the region. More studies are needed to investigate the long-term effects and doseresponse relationship of arsenic in the region and similar areas. Wide-ranging monitoring programmes for drinking-water sources should be implemented by public-health authorities.
\end{abstract}

Key words: Arsenic; Cross-sectional studies; Dermatological lesions; Hypertension; Chromosomal abnormalities; Water pollution; Water supply; Iran

\section{INTRODUCTION}

Arsenic is a hazardous, naturally-occurring element widely distributed in the crust of the earth. Inorganic forms of arsenic (pentavalent and trivalent forms) can be found in small amounts in the atmosphere, groundwater, and surface-water. Exposure to

Correspondence and reprint requests should be addressed to:

Dr. Mohammad Mosaferi

School of Public Health and Nutrition

Tabriz University of Medical Sciences

Tabriz

Iran

Email: mosaferim@tbzmed.ac.ir

Fax: +984113340634 arsenic compounds is a major concern to public health in both developing and developed countries $(1,2)$. Arsenic is an ingredient of a wide variety of products in manufacturing industries, i.e. wood preservatives, herbicides, insecticides, pesticides, fungicides, high-emitting diodes, semi-conductors, etc., thus making workplaces a source of inhalation of, and dermal exposure to, arsenic. Arsenical drugs have also been used for treating some medical conditions $(3,4)$. However, the main source of high exposure of general population to arsenic compounds is water. Arsenic in drinking-water above the accepted standards demonstrated in many countries is a global problem affecting countries on all five continents (5). In some countries of Asia, the issue of chronic arsenic intoxication seems to 
be a more important public-health problem than in other regions of the world (6). In Asia, arsenic has been reported in groundwater in Bangladesh, Cambodia, China (including provinces of Taiwan and Inner Mongolia), India, Iran, Japan, Myanmar, Nepal, Pakistan, Thailand, and Viet Nam (5). The most serious damage to health has taken place in Bangladesh and West Bengal, India $(5,7)$.

In Iran, naturally-occurring arsenic is responsible for contamination in drinking-water. Kurdistan, a western province of the country, is having a major problem of arsenic contamination $(8,9)$.

A recent study in the villages of Hashtrud county, in the northwest of the country, showed that arsenic exists in the drinking-water at a higher level (10) than the World Health Organization (WHO) guideline value of $10 \mu \mathrm{g} / \mathrm{L}$ (11) and the national Iranian standard value of $50 \mu \mathrm{g} / \mathrm{L}$ (12) in a quarter of the villages in this area.

The acute toxicity of arsenic at high concentrations has been known about for centuries. A strong adverse effect of low arsenic concentrations was recently discovered to be associated with long-term exposure. Drinking-water is now recognized as the major source of human intake of arsenic in its most toxic (inorganic) forms (5).

A number of studies have been reported to assess the effects of arsenic-contaminated food (13) and water in those communities with high level of contamination (13-18).

The disease symptoms caused by chronic arsenic ingestion are called arsenicosis and develop when arsenic-contaminated water is consumed for several years (5).

Although some adverse effects on health have been reported for chronic arsenic exposure, it varies by different population groups, age, gender, cumulative dose of arsenic, nutritional status, genetic factors, lifestyle, individual susceptibility, and different chemical forms of arsenic in drinking-water (19-22).

Many studies have been reported on the relationship of chronic arsenic exposure with cardiovascular diseases (23-24), cerebrovascular events $(25,26)$, hypertension and peripheral vascular disorders (2732), Blackfoot disease (33), carcinogenic effects (34$43)$, diabetes $(44,45)$, some neurological diseases (46-47), skin disorders (48-50), and chromosomal abnormalities (51-56).

The first visible symptoms caused by exposure to low arsenic concentrations in drinking-water are abnormal black-brown skin-pigmentation known as melanosis and hardening of palms and soles known as keratosis. If the exposure continues, skindepigmentation is started, resulting in white spots that look like raindrops (medically described as leukomelanosis). Palms and soles further thicken and painful cracks emerge. These symptoms are described as hyperkeratosis and can lead on to skin cancer (57).

The aim of this study was to investigate the effects of chronic exposure to arsenic on dermatological lesions, hypertension, and chromosomal abnormalities in a region in the northwest of Iran.

\section{MATERIALS AND METHODS}

\section{Setting and subjects}

East Azerbaijan province is located in the northwest of Iran with a cool and dry climate (Fig.) that covers an area of approximately $47,830 \mathrm{sq} \mathrm{km}$. It has a population of around four million. The province has common borders with the current Republics of Azerbaijan, Armenia, and Nakhchivan (58). This cross-sectional study was carried out in Ghopuz village (chronically exposed to arsenic) and Mayan village (control group). Both the villages are located in the East Azerbaijan province.

Selected villages were similar, considering the ethnic, cultural background, and other socioeconomic factors. In Ghopuz, occupation of all people was agriculture. However, in Mayan, there were other occupations along side agriculture because of less distance to Tabriz (capital city of the province).

In Ghopuz, all people aged six years and more were included as exposure group (total number

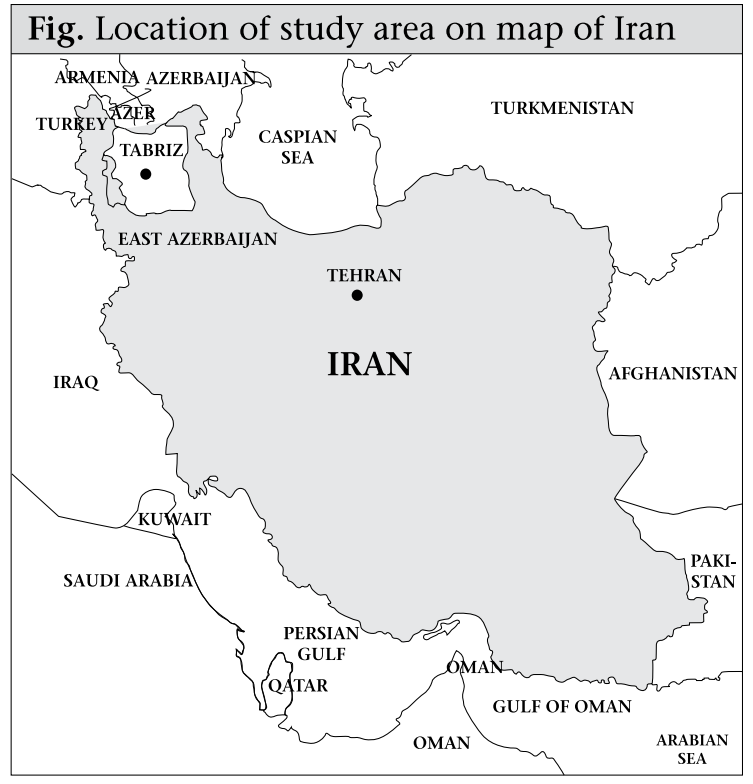


of subjects was $101-48$ male and 53 female). The reason for selecting subjects aged $\geq 6$ years was the status of exposure: exposure of subjects had been removed by local water and wastewater authorities since five years before our study. In the meantime, those people aged $\geq 5$ years were allowed to have at least one year of exposure to arsenic in their drinking-water. We, therefore, included everyone aged $\geq 6$ years for this study. This means that every subject (aged $\geq 6$ years) in our study had at least one year of exposure to arsenic. For further uniformity, same criteria were considered in the control village. The control group was selected from Mayan with no arsenic in drinking-water as the main selection factor. A random-sampling method was applied, and 107 subjects (41 male and 66 female) were selected as a control group. During the study, fortunately all the selected subjects had good cooperation with the research team, and the refusal rate was zero. Physical examination was carried out in the premise of the village's alderman in Ghopuz and in the governmental health facility in Mayan. Before physical examination, verbal consent of the participants was obtained. Table 1 presents the characteristics of the study subjects.

\section{Sampling and analysis of water}

There were three springs and a polyethylene reservoir as drinking-water sources in Ghopuz village. Water of one spring was used via the water-distribution network. However, in Mayan, well-water was available via the distribution network as the only water source. Water samples were collected in plastic bottles cleaned with nitric acid and distilled water. Two following sets of samples were collected:

The first sample was used in measuring the common parameters, including cations $\left(\mathrm{Ca}^{2+}, \mathrm{Mg}^{2+}\right.$, $\left.\mathrm{Na}^{+}, \mathrm{K}^{+}\right)$, anions $\left(\mathrm{HCO}_{3}^{-}, \mathrm{SO}_{4}{ }^{2-}, \mathrm{Cl}^{-}\right)$, total dissolved solids (TDS), electrical conductivity (EC), hardness, alkalinity, and $\mathrm{pH}$ according to the Standard Methods for the Examination of Water and Wastewater (20th edition, 1998) (59).
The second sample was used in assessing heavy metal concentration (As, Se, Cd, Cr, Pb, Fe, Mn) in drinking-water using inductively-coupled plasma (ICP) method after acidification with nitric acid. Concentration of detection limits for each of the above elements was 70, 75, 6, 10, 64, 10, and $2 \mu \mathrm{g} / \mathrm{L}$ respectively. Quality control of analysis was carried out using standard solutions and plotting standard calibration curve before analysis of water samples.

To achieve a mean annual concentration of arsenic in drinking-water sources, we focused on measurement of arsenic in the sampling programme. So, measurement of arsenic was continued for one year. The results of quality analysis of drinking-water sources in Ghopuz during the past years were also collected. A structured questionnaire was used for collecting information on the type of water source, history of consumption, and changes over time.

\section{Definition and measurement of outcomes}

Three sets of outcomes were measured, including prevalence of dermatological lesions (hyperkeratosis and pigmentation abnormalities), hypertension, and chromosomal abnormalities.

Exposure to arsenic was defined as consumption of drinking-water with arsenic concentration more than $50 \mu \mathrm{g} / \mathrm{L}$ for at least one year. Individuals with residency less than one year in the village were excluded from the study.

Unexposed individuals were defined as those subjects who consumed arsenic through drinkingwater with a concentration of $50 \mu \mathrm{g} / \mathrm{L}$ or less.

After obtaining an informed consent from the participants, a specialist physician performed physical and clinical examinations. During the study, the physician was aware of exposure status. To provide a more accurate diagnosis for the skin lesions, the physicians on the research team referred to the guidelines published by the United Nations (60)

\begin{tabular}{|c|c|c|c|c|}
\hline \multirow{2}{*}{ Factors assessed } & \multicolumn{2}{|c|}{ Ghopuz } & \multicolumn{2}{|c|}{ Mayan } \\
\hline & Mean (SD) & $95 \% \mathrm{CI}$ & Mean (SD) & $95 \% \mathrm{CI}$ \\
\hline CAI (g) & $14.7(10.9)$ & $12.1-17.3$ & $0(0)$ & 0 \\
\hline Age (years) & $33.8(16.1)$ & $29.9-37.6$ & $29.6(17.9)$ & 25.9-33.1 \\
\hline Residence (year) & $29.7(15.3)$ & $26.1-33.4$ & $28.9(17.9)$ & $25.3-32.5$ \\
\hline BMI $\left(\mathrm{kg} / \mathrm{m}^{2}\right)$ & $23.6(4.5)$ & $22.5-24.7$ & $22.5(5.8)$ & $21.3-23.7$ \\
\hline Systolic blood pressure (mmHg) & $137(20.2)$ & $132-142$ & $107(34.9)$ & 99.9-114 \\
\hline Diastolic blood pressure (mmHg) & $82(11.5)$ & $79-85$ & $71(22.1)$ & $66-75$ \\
\hline
\end{tabular}


and pictures available on web sources before the start of the study. During the physical examinations and after measurement of height and weight, a physician interviewed each participant for the presence of skin-lesions, discomfort, and other diseases, if any, followed by auscultation and observation of the degree of skin-hyperpigmentation, hyperkeratosis, and the severity of each lesion covering the body-surface. A questionnaire was filled for each individual during face-to-face interviews. The questionnaire contained information on age, height, weight, blood pressure, skin-lesions and its severity, location and history of these lesions, smoking, residence, and family history. We did not gather educational information and housing condition of the participants. Blood pressure of each participant was determined once in sitting position after at least 10 minutes of resting using a sphygmo portable-grade Richter manometer. Body mass index (BMI) was determined as an indicator of malnutrition status.

Cumulative arsenic index (CAI) was calculated for all the subjects (9). Lifetime dose of arsenic for each individual was then estimated on the basis of age, arsenic concentration of water sources, and location of residence using the following formula:

$\mathrm{CAI}=\sum \mathrm{di} \times \mathrm{AIAi}$

$\mathrm{AIAi}=\mathrm{Ci} \times 1 \mathrm{~g} / 1,000 \mathrm{mg} \times \mathrm{LPCD} \times 365$ days/year

Where:

CAI is the total lifetime intake of arsenic from drinking-water $(\mathrm{g})$,

di is the duration of the $\mathrm{i}^{\text {th }}$ water source used by each individual (in year),

AIAi is the annual intake of arsenic through consumed water in the form of water or tea $(\mathrm{g} /$ year),

$\mathrm{Ci}$ is the mean annual concentration of arsenic in drinking-water $(\mathrm{mg} / \mathrm{L})$

LPCD (litre per capita per day) is the volume of drinking-water consumed by each individual in the form of water or tea (L/day).

\section{Chromosomal analysis}

We investigated the occurrence of chromosomal abnormalities in subjects with chronic exposure to arsenic in drinking-water (from Ghopuz) and a matched control group with no exposure to arsenic (from Mayan). For chromosomal analysis, peripheral blood samples were assessed by micro-culture method (Difco Laboratory method), Gimsa staining, and G-banding of chromosomes. Chromosomal analysis was blinded.

\section{Statistical analysis}

Descriptive statistics (including proportions, means, and standard deviations), 95\% confidence intervals, chi-square test, and odds ratios were used for statistical analysis of data. The $p$ value of $\leq 0.05$ was considered significant. The SPSS software (version 10.0) was used for statistical analysis.

\section{RESULTS}

Table 2 presents the results of analysis of water in the exposure group and control group. In the exposure group, the hardness of water was almost in the range of 'hard to very hard', and $\mathrm{pH}$ of water was more than 7. A remarkable finding in the exposure group was high amounts of nitrate in drinking-water samples taken from no-piped springs in the village (about three times more than the standard level). The results of analysis of samples from

\begin{tabular}{|c|c|c|}
\hline $\begin{array}{l}\text { Characteristics of } \\
\text { drinking-water }\end{array}$ & $\begin{array}{l}\text { Ghopuz } \\
\text { (Exposure } \\
\text { group) }\end{array}$ & $\begin{array}{l}\text { Mayan } \\
\text { (Control } \\
\text { group) }\end{array}$ \\
\hline $\begin{array}{l}\text { Electrical } \\
\text { conductivity }(\mu \mathrm{s} / \mathrm{cm})\end{array}$ & $1,044.8$ & 701 \\
\hline $\mathrm{pH}$ & 8.24 & 8.3 \\
\hline $\begin{array}{l}\text { Total dissolved solid } \\
(\mathrm{mg} / \mathrm{L})\end{array}$ & 689.8 & 463 \\
\hline $\begin{array}{l}\text { Phenol alkalinity } \\
\left(\mathrm{mg} / \mathrm{L} \text { as } \mathrm{CaCO}_{3}\right)\end{array}$ & 2.5 & 0 \\
\hline $\begin{array}{l}\text { Methyl alkalinity } \\
\left(\mathrm{mg} / \mathrm{L} \text { as } \mathrm{CaCO}_{3}\right)\end{array}$ & 300 & 185 \\
\hline $\begin{array}{l}\text { Total hardness (mg/ } \\
\left.\mathrm{L} \text { as } \mathrm{CaCO}_{3}\right)\end{array}$ & 362.5 & 210 \\
\hline Calcium (mg/L) & 92.5 & 44 \\
\hline Magnesium (mg/L) & 31.5 & 24 \\
\hline Sodium $(\mathrm{mg} / \mathrm{L})$ & 88.9 & 75 \\
\hline Potassium (mg/L) & 6.5 & 3.6 \\
\hline Chloride (mg/L) & 54.9 & 78 \\
\hline Sulphate (mg/L) & 83.9 & 70.6 \\
\hline Nitrite $(\mathrm{mg} / \mathrm{L})$ & 0.033 & 0 \\
\hline Nitrate (mg/L) & 111.6 & 8.5 \\
\hline Iron $(\mathrm{mg} / \mathrm{L})$ & 0.0465 & 0.102 \\
\hline Manganese (mg/L) & 0.001 & 0.002 \\
\hline Cadmium (mg/L) & 0 & 0 \\
\hline Arsenic (mg/L) & $1.031^{*}$ & 0 \\
\hline Selenium (mg/L) & 0.0075 & 0.007 \\
\hline Chromium (mg/L) & 0 & 0 \\
\hline Lead (mg/L) & 0 & 0 \\
\hline
\end{tabular}


Mayan also showed the presence of minerals in water, indicating the hardness of water in the control group.

Arsenic contamination was detected in water sources of the exposed subjects. Analyses of other elements showed a slightly higher concentration of selenium in the exposure group. In the water samples from Mayan (control group), we did not find any amount of arsenic. Interestingly, there was no high amount of manganese, along with arsenic.

General characteristics of the study subjects are presented in Table 1. No significant effect was observed for cigarette-smoking $(\mathrm{p}=0.55)$. The mean systolic blood pressure in Ghopuz $(n=137,95 \%$ CI 132142) was significantly higher than from the control subjects $(n=107,95 \%$ CI 99.9-114). The same difference was observed for diastolic blood pressure (Ghopuz: $n=82,95 \%$ CI 79-85; Mayan: $n=71,95 \%$ CI 66-75).

Table 3 shows a comparison of dermatological lesions and chromosomal abnormalities in the exposure group and control group. The incidence of hyperkeratosis was 34 times higher among the exposed individuals compared to those in the control group $(\mathrm{OR}=34, \mathrm{p}<0.001)$. The same difference was found in the location and severity of the lesions. Palmar hyperkeratosis was observed in one subject in each group $(\mathrm{p}>0.1)$.

A significant difference was found in the occurrence of skin-pigmentation, location and severity of pigmentations between the two groups $(\mathrm{OR}=2.4$, $\mathrm{p}<0.007)$. Concurrent pigmentation in limbs, trunk, and tongue was observed in two of the exposed subjects and nine in the controls. This difference was not statistically significant $(\mathrm{OR}=0.24, \mathrm{p}=0.17)$.

\section{DISCUSSION}

Cutaneous abnormalities and lesions are the most common outcome and health effects from consumption of drinking-water containing arsenic. Typically, the cutaneous abnormalities and lesions are diagnosed as keratosis and pigment disorder, including hyperpigmentation and hypopigmentation. We studied the effects of chronic exposure to arsenic on dermatological lesions, hypertension and chromosomal abnormalities in a region in the northwest of Iran. The findings showed a high prevalence of skin disorders in individuals who consumed water with high concentrations of arsenic.

The results of the study showed that, in the arsenicaffected village, 30 (30.6\%) subjects had hyperkeratosis, and 23 (23\%) subjects had hyperpigmenta- tion. However, in the control village, we found one person $(0.9 \%)$ with keratosis and 10 persons $(9.3 \%)$ with pigmentation.

A study at Guo in Inner Mongolia found that the prevalence of keratosis was higher than pigment disorder. There was a clear exposure-response relationship between the prevalence of pigmented lesions and the levels of arsenic (61).

Mosaferi et al. studied 752 subjects in Kurdistan province of Iran in eight villages of Bijar county. They found a significant correlation of chronic arsenic exposure with hyperkeratosis and hyperpigmentation. There was also a significant relationship between total lifetime intake of arsenic and keratosis, pigmentation, systolic and diastolic blood pressures, and hair arsenic content $(9,62)$.

In the study of Tondel in Bangladesh, morbidity from skin-lesions included almost one-third of the population which is similar to our study (63).

Cumulative arsenic index (CAI) has been shown to be associated with hypertension in a dose-response. This index is able to well-reflect the cumulative dosage of lifetime exposure to arsenic via drinkingwater in individual subjects.

The study of Huang further explored the association between arsenic methylation capability and hypertension risk among residents of arseniasis hyper-endemic areas in Taiwan (64). The findings suggested that hypertensive subjects had higher urinary monomethylarsonic acid $\left(\mathrm{MMA}^{\mathrm{v}}\right)$ percentage and lower secondary arsenic methylation index (SMI) than subjects without hypertension (64).

Other investigations in Taiwan and Bangladesh have shown that subjects with prolonged exposure to inorganic arsenic have a significantly higher risk of hypertension in a dose-response pattern $(27,28)$.

A cross-sectional study on 8,790 pregnant women observed increased systolic blood pressure levels with increasing arsenic contents in drinking-water (65). Our study has shown that subjects with high CAI had higher blood pressure even after stopping consumption of contaminated water for five years.

In Iran, the delayed effects of exposure to arsenic on health, incomplete monitoring of chemical quality, technical limitation for analysis of arsenic, the lack of common definitions, poor awareness, and reporting in the region are the major problems in determining the extent of the arsenic problem in drinking-water. It seems, therefore, necessary to create a reliable databank and information system 


\begin{tabular}{|c|c|c|c|c|c|}
\hline \multirow{2}{*}{ Disorder } & \multicolumn{2}{|c|}{ Ghopuz } & \multicolumn{2}{|c|}{ Mayan } & \multirow{2}{*}{$\begin{array}{c}\text { Statistical } \\
\text { significance }\end{array}$} \\
\hline & No. & $\%$ & No. & $\%$ & \\
\hline \multicolumn{6}{|l|}{ Keratosis } \\
\hline No & 68 & 68.7 & 105 & 99.1 & \multirow[t]{2}{*}{$\mathrm{OR}=34, \mathrm{p}<0.001$} \\
\hline Yes & 31 & 31.3 & 1 & 0.9 & \\
\hline \multicolumn{6}{|l|}{ Location of keratosis } \\
\hline No keratosis & 68 & 68.7 & 105 & 99.1 & \multirow[b]{2}{*}{$\mathrm{OR}=1.1, \mathrm{p}>0.10$} \\
\hline Hands & 1 & 1 & 1 & 0.9 & \\
\hline Feet & 21 & 21.2 & 0 & 0 & $\mathrm{p}<0.001$ \\
\hline Both hands and feet & 9 & 9.1 & 0 & 0 & $\mathrm{p}<0.001$ \\
\hline \multicolumn{6}{|l|}{ Severity of keratosis } \\
\hline No keratosis & 68 & 68.7 & 105 & 99.1 & \multirow{3}{*}{$\begin{array}{c}\mathrm{OR}=23, \mathrm{p}<0.001 \\
\mathrm{p}<0.001\end{array}$} \\
\hline Mild & 21 & 21.2 & 1 & 0.9 & \\
\hline Moderate & 10 & 10.1 & 0 & 0 & \\
\hline \multicolumn{6}{|l|}{ Pigmentation } \\
\hline No & 77 & 77 & 97 & 90.7 & \multirow[b]{2}{*}{$\mathrm{OR}=2.4, \mathrm{p}=0.007$} \\
\hline Yes & 23 & 23 & 10 & 9.3 & \\
\hline \multicolumn{6}{|l|}{ Location of pigmentation } \\
\hline No pigmentation & 77 & 77 & 97 & 90.7 & \multirow{4}{*}{$\begin{array}{c}\mathrm{p}<0.001 \\
\mathrm{p}<0.001 \\
\mathrm{OR}=0.24, \mathrm{p}=0.17\end{array}$} \\
\hline Limbs & 0 & 0 & 1 & 0.9 & \\
\hline Limbs and trunk & 21 & 21 & 0 & 0 & \\
\hline Limbs, trunk, and tongue & 2 & 2 & 9 & 8.4 & \\
\hline \multicolumn{6}{|l|}{ Severity of pigmentation } \\
\hline No pigmentation & 77 & 77 & 97 & 92.4 & \multirow{4}{*}{$\begin{array}{c}\mathrm{OR}=2.1, \mathrm{p}<0.001 \\
\mathrm{OR}=3.7, \mathrm{p}<0.001 \\
\mathrm{p}<0.001\end{array}$} \\
\hline Mild & 8 & 8 & 4 & 3.8 & \\
\hline Moderate & 14 & 14 & 4 & 3.8 & \\
\hline Severe & 1 & 1 & 0 & 0 & \\
\hline \multicolumn{6}{|l|}{ Chromosomal abnormalities } \\
\hline No abnormalities & 18 & 75 & 18 & 81.8 & \multirow{6}{*}{$\mathrm{p}<0.05$} \\
\hline 21 Trisomy & 0 & 0 & 2 & 9.1 & \\
\hline Chromatide cleavage & 0 & 0 & 2 & 9.1 & \\
\hline Endo-reduplication & 2 & 8.3 & 0 & 0 & \\
\hline $\begin{array}{l}\text { Endo-reduplication, gap and } \\
\text { acentric fragment }\end{array}$ & 1 & 4.1 & 0 & 0 & \\
\hline $\begin{array}{l}\text { Acentric fragment and } 45-(-\mathrm{x} \\
\text { or -C)/47- chromosomes }\end{array}$ & 3 & 12.5 & 0 & 0 & \\
\hline OR=Odds ratio & & & & & \\
\hline
\end{tabular}

for chemical quality of drinking-water in some suspicious polluted areas in the country.

Our study had some limitations. The physician was aware of exposure status. Determination of skinmanifestation in the exposure group and control group was not, therefore, blind. Blood pressure was measured once only while it is recommended to repeat the measurement 2-3 times for a valid result. For calculation of CAI value, it was difficult to obtain and calculate accurate data of water consumption for each individual and the duration of exposure to arsenic.
In Ghopuz village, an important concern was the consumption of contaminated water by livestock because of the shortage of safe water in the region. Results of a study in Argentina showed that contamination in water supply for livestock may lead to contamination of dairy (66). This emphasizes the necessity of monitoring the chemical profile of water sources in livestock too, even if there is no detectable/considerable contamination in water supply for humans. Another important issue in dealing with arsenic-related problems is public education, particularly in the communities with low socioeconomic status. 
The study concludes that arsenic exposure is a serious health problem in the region. More studies are needed to investigate the long-term effects and dose-response relationship of arsenic in the region and similar areas. Wide-ranging monitoring programmes of drinking-water sources should be implemented by public-health authorities.

Geo-coding of contaminated areas (using the Geographical Information System) and monitoring the contamination rate of soil and agricultural products in arsenic-contaminated areas may also help prevent further similar problems in the region.

\section{ACKNOWLEDGEMENTS}

The authors thank the East Azerbaijan Sciences and Technology Park for funding this project. The authors also thank all the participants in this project in East Azerbaijan for their hospitality and assistance during the study and data collection. They are grateful of Dr. Kusha and Dr. Seyf Farshad for their help in coordination and management of the project.

\section{REFERENCES}

1. Agency for Toxic Substances and Disease Registry. Toxicological profile for arsenic TP2. Atlanta, GA: Centers for Disease Control and Prevention, 2005:115.

2. World Health Organization. Arsenic and arsenic compounds. 2nd ed. Geneva: World Health Organization, 2001:1-8. (Environmental health criteria, v. 224).

3. Rousselot P, Laboume S, Marolleau JP, Larghero T, Noguera ML, Brouet JC et al. Arsenic trioxide and melarsoprol induce apoptosis in plasma cell lines and in plasma cells from myeloma patient. Cancer Res 1999;59:1041-8.

4. Evens AM, Tallman MS, Gartenhaus RB. The potential of arsenic trioxide in the treatment of malignant disease: past, present, and future. Leukemia Res 2004;28:891-900.

5. Petrusevski B, Sharma SK, Schippers JC, Shordt K. Arsenic in drinking water. Delft: IRC International Water and Sanitation Centre, 2007:1-11 (Thematic overview paper no. 17).

6. Tseng $\mathrm{CH}$. Cardiovascular disease in arsenic-exposed subjects living in the arseniasis-hyperendemic areas in Taiwan (review). Atherosclerosis 2008;199:12-8.

7. Rahman MM, Chowdhury UK, Mukherjee SC, Mondal BK, Paul K, Lodh D et al. Chronic arsenic toxicity in Bangladesh and West Bengal, India, a review and commentary. J Toxicol Clin Toxicol 2001;39:683-700.

8. Mukherriee A, Sengupta MK, Hossain MA, Ahamed
S, Das B, Navak B et al. Arsenic contamination in groundwater: a global perspective with emphasis on the Asian scenario. J Health Popul Nutr 2006;24:14263.

9. Mosaferi M, Yunesian M, Dastgiri S. Mesdaghinia A, Esmailnasab N. Prevalence of skin lesions and exposure to arsenic in drinking water in Iran. Sci Total Environ 2008;390:69-76.

10. Mosaferi M, Hassani AM, Borghei M, Kamali Z, Ghadirzadeh A. Study of arsenic presence in drinking water sources: a case study. Iran J Health Environ 2008;1:1827 [Persian].

11. World Health Organization. Guidelines for drinkingwater quality. Geneva: World Health Organization, 1993:41.

12. Institute of Standard and Industrial Research of Iran. Drinking water characteristics. Standard number 1053. $4^{\text {th }}$ ed. Tehran: Institute of Standard and Industrial Research of Iran, 1996:5.

13. Uchino T, Roychowdhury T, Ando M, Tokunaga $\mathrm{H}$. Intake of arsenic from water, food composites and excretion through urine, hair from a studied population in West Bengal, India. Food Chem Toxicol 2006;44:455-61.

14. Yoshida T, Yamauchi H, Sun GF. Chronic health effects in people exposed to arsenic via the drinking water-dose response relationships in review. Toxicol Appl Pharmacol 2004;198:243-52.

15. Nickson R, McArthur J, Burgess W, Ahmed KM, Ravenscroft P, Rahman M. Arsenic poisoning of Bangladesh groundwater (letter). Nature 1998;395:338.

16. Gebel TW. Arsenic and drinking water contamination. Science 1999;283:1458-9.

17. Sun G. Arsenic contamination and arsenicosis in China. Toxicol Appl Pharmacol 2004;198:268-71.

18. Kapaj S, Peterson H, Liber K, Bhattacharya P. Human health effects from chronic arsenic poisoning: a review. J Environ Sci Health A: Tox Hazard Subst Environ Eng 2006;41:2399-428.

19. Tsuchiya K. Various factors influencing toxicity and metabolism of metals--metal-metal interactions and host factors [author's transl]. Sangyo Igaku 1977;19:471-8.

20. Ferreccio C, Sancha AM. Arsenic exposure and its impact on health in Chile. J Health Popul Nutr 2006;24:164-75.

21. Mitra SR, Mazumder DN, Basu A, Block G, Haque R, Samanta $S$ et al. Nutritional factors and susceptibility to arsenic-caused skin lesions in West Bengal, India. Environ Health Perspect. 2004;112:1104-9.

22. Kristiansen J, Christensen JM, Iversen BS, Sabbioni E. Toxic trace element reference levels in blood and 
urine: influence of gender and lifestyle factors. Sci Total Environ 1997;204:147-60.

23. Navas-Acien A, Sharret AR, Silbergeld EK, Schwartz BS, Nachman KE, Burke TA et al. Arsenic exposure and cardiovascular disease: a systematic review of the epidemiologic evidence. Am J Epidemiol 2005;162:103749.

24. Tseng CH, Chong CK, Tseng CP, Hsueh YM, Chiou $\mathrm{HY}$, Tseng CC et al. Long-term arsenic exposure and ischemic heart disease in arseniasis-hyperendemic villages in Taiwan. Toxicol Lett 2003;137:15-21.

25. Chiou HY, Huang WI, Su CL, Chang SF, Hsu YH, Chen CJ. Dose-response relationship between prevalence of cerebrovascular disease and ingested inorganic arsenic. Stroke 1997;28:1717-23.

26. Wang CH, Jeng JS, Yip PK, Chen CL, Hsu LI, Hsueh $\mathrm{YM}$ et al. Biological gradient between long-term arsenic exposure and carotid atherosclerosis. Circulation 2002;105:1804-9.

27. Chen CJ, Hsueh YM, Lai MS, Shyu MP, Chen SY, Wu $\mathrm{MM}$ et al. Increased prevalence of hypertension and long-term arsenic exposure. Hypertension 1995;25:5360.

28. Rahman M, Tondel M, Ahmad SA, Chowdhury IA, Faruquee MH, Axelson O. Hypertension and arsenic exposure in Bangladesh. Hypertension 1999;33:74-8.

29. Engel RR, Hopenhayn-Rich C, Receveur O, Smith AH. Vascular effects of chronic arsenic exposure: a review. Epidemiol Rev 1994;16:184-209.

30. Simeonova PP, Luster MI. Arsenic and atherosclerosis. Toxicol Appl Pharmacol 2004;198:444-9.

31. Tseng CH, Chong CK, Chen CJ, Tai TY. Dose-response relationship between peripheral vascular disease and ingested inorganic arsenic among residents in blackfoot disease endemic villages in Taiwan. Atherosclerosis 1996;120:125-33.

32. Kumagai Y, Pi J. Molecular basis for arsenic-induced alteration in nitric oxide production and oxidative stress: implication of endothelial dysfunction. Toxicol Appl Pharmacol 2004;198:450-7.

33. Tseng WP. Blackfoot disease in Taiwan: a 30-year follow-up study. Angiology 1989;40:547-58.

34. Chen CJ, Wang CJ. Ecological correlation between arsenic level in well water and age-adjusted mortality from malignant neoplasms. Cancer Res 1990;50:5470-4.

35. Chen CJ, Chuang YC, Lin TM, Wu HY. Malignant neoplasms among residents of a blackfoot diseaseendemic area in Taiwan: high-arsenic artesian well water and cancers. Cancer Res 1985;45:5895-9.

36. Chen CJ, Chen CW, Wu MM, Kuo TL. Cancer potential in liver, lung, bladder and kidney due to in- gested inorganic arsenic in drinking water. Br J Cancer 1992;66:888-92.

37. Chiou HY, Chiou ST, Hsu YH, Chou YL, Tseng CH, Wei ML et al. Incidence of transitional cell carcinoma and arsenic in drinking water: a follow-up study of 8102 residents in an arseniasis-endemic area in northeastern Taiwan. Am J Epidemiol 2001;153:411-8.

38. Schwerdtle T, Walter I, Mackiw I, Hartwig A. Induction of oxidative DNA damage by arsenite and its trivalent and pentavalent methylated metabolites in cultured human cells and isolated DNA. Carcinogenesis 2003;24:967-74.

39. Yu HS, Liao WT, Chai CY. Arsenic carcinogenesis in the skin. J Biomed Sci 2006;13:657-66.

40. Chiou HY, Hsueh YM, Liaw KF, Horng SF, Chiang $\mathrm{MH}, \mathrm{Pu}$ YS et al. Incidence of internal cancers and ingested inorganic arsenic: a seven-year follow-up study in Taiwan. Cancer Res 1995;55:1296-300.

41. Liu YT, Chen Z. A retrospective lung cancer mortality study of people exposed to insoluble arsenic and radon. Lung Cancer 1996;14:137-48.

42. Abernathy C, Morgan A. Exposure and health effects. Chapter 3: United Nations synthesis report on arsenic in drinking water (first draft). Washington, DC: Office of Water, Health and Ecological Criteria Division, US Environmental Protection Agency, 2001:71.

43. Tapio S, Grosche B. Arsenic in the aetiology of cancer. Mutation Res 2006;612:215-46.

44. Navas-Acien A, Silbergeld EK, Streeter RA, Clark JM, Burke TA, Guallar E. Arsenic exposure and type 2 diabetes: a systematic review of the experimental and epidemiologic evidence. Environ Health Perspect 2006;114:641-8.

45. Tseng CH, Tseng CP, Chiou HY, Hsueh YM, Chong CK, Chen CJ. Epidemiologic evidence of diabetogenic effect of arsenic. Toxicol Lett 2002;133:69-76.

46. Calderon J, Navarro ME, Jimenez-Capdeville ME, Santos-Diaz MA, Golden A, Rodriguez-Leyva I et al. Exposure to arsenic and lead and neuropsychological development in Mexican children. Environ Res 2001;85:69-76.

47. Grandjean P, Landrigan PJ. Developmental neurotoxicity of industrial chemicals. Lancet 2006;368:216778.

48. Yoshida T, Yamauchi H, Fan Sun G. Chronic health effects in people exposed to arsenic via the drinking water: dose-response relationships in review. Toxicol Appl Pharmacol 2004;198:243-52.

49. Mazumder DNG. Chronic arsenic toxicity: clinical features, epidemiology, and treatment: experience in West Bengal. J Environ Sci Health A: Tox Hazard Subst Environ Eng 2003;38:141-63. 
50. Tseng WP. Effects and dose-response relationships of skin cancer and blackfoot disease with arsenic. Environ Health Perspect 1977;19:109-19.

51. Wang YH, Wu MM, Hong CT, Lien LM, Hsieh YC, Tseng HP et al. Effects of arsenic exposure and genetic polymorphisms of p53, glutathione S-transferase M1, T1, and P1 on the risk of carotid atherosclerosis in Taiwan. Atherosclerosis 2007;192:305-12.

52. Mahata J, Chaki M, Ghosh P, Das LK, Baidya K, Ray $\mathrm{K}$ et al. Chromosomal aberrations in arsenic-exposed human populations: a review with special reference to a comprehensive study in West Bengal. India. $C y$ togenet Genome Res 2004;104:359-64.

53. Sordo M, Herrera LA, Ostrosky-Wegman P, Rojas E. Cytotoxic and genotoxic effects of As, MMA, and DMA on leukocytes and stimulated human lymphocytes. Teratog Carcinog Mutagen 2001;21:249-60.

54. Abernathy CO, Liu YP, Longfellow D, Aposhian HV, Beck B, Fowler B et al. Arsenic: health effects, mechanisms of actions, and research issues. Environ Health Perspect 1999;107:593-7.

55. Dopp E, Hartmann LM, Florea AM, von Recklinghausen U, Pieper R, Shokouhi B et al. Uptake of inorganic and organic derivatives of arsenic associated with induced cytotoxic and genotoxic effects in Chinese hamster ovary (CHO) cells. Toxicol Appl Pharmacol 2004;201:156-65.

56. Hughes MF. Arsenic toxicity and potential mechanisms of action. Toxicol Lett 2002;133:1-16.

57. Chen CJ, Hsueh YM, Chiou HY, et al. Human carcinogenicity of inorganic arsenic. In: Abernathy CO, Calderon RL, Chappell WR, editors. Arsenic: exposure and health effects. London: Chapman and Hall Ltd., 1997:232-42.
58. Iran national portal of statistics. 2008. (http://www. sci.org.ir/portal/faces/public/sci, accessed 16 May 2009).

59. Clesceri LS, Greenberg AE, Eaton AD, editors. Standard methods for the examination of Water and wastewater. $20^{\text {th }}$ ed. Washington, DC: American Public Health Association, 1998. 1,325 p.

60. Guha Mazumder DN. Diagnosis and treatment of chronic arsenic poisoning. Geneva: World Health Organization, 2000:1-45.

61. Guo X, Liu Z, Huang C, You L. Levels of arsenic in drinking water and cutaneous lesions in Inner Mongolia. J Health Popul Nutr 2006;24:214-20.

62. Mosaferi M, Yunesian M, Mesdaghinia AR, Nasseri S, Mahvi AH, Nadim H. Correlation between arsenic concentration of drinking water and hair. Iran J Environ Health Sci Eng 2005;2:11-23.

63. Tondel M, Rahman M, Magnuson A, Chowdhury IA, Faruquee $\mathrm{MH}$, Ahmad SA. The relationship of arsenic levels in drinking water and the prevalence rate of skin lesions in Bangladesh. Environ Health Perspect 1999;107:727-9.

64. Huang YK, Tseng CH, Huang YL, Yang MH, Chen CJ, Hsueh YM. Arsenic methylation capability and hypertension risk in subjects living in arseniasis-hyperendemic areas in southwestern Taiwan. Toxicol Appl Pharmacol 2007;218:135-42.

65. Ling HL, Xia Y, Lobdell D, Zeng D, Thorp JM, Creason JP et al. Drinking water arsenic exposure and blood pressure in healthy women of reproductive age in Inner Mongolia, China. Toxicol Appl Pharmacol 2007;222:337-43.

66. Perez-Carrera A, Fernandez-Cirelli A. Arsenic concentration in water and bovine milk in Cordoba, Argentina: preliminary results. J Dairy Res 2005;72:122-4. 